\title{
Receptor-interacting protein kinase 3 is a predictor of survival and plays a tumor suppressive role in colorectal cancer
}

\author{
X. FENG ${ }^{1}$, Q. SONG ${ }^{1}$, A. YU 1 , H. TANG ${ }^{2}$, Z. PENG ${ }^{3}, \mathrm{X} . \mathrm{WANG}^{1, *}$ \\ ${ }^{1}$ Department of Basic Medicine, Taishan Medical University, Taian, Shandong, 271016, China; ${ }^{2}$ Department of Pathology, Shanghai Jiaotong \\ University Affiliated First People's Hospital, Shanghai 200080, People's Republic of China; ${ }^{3}$ Department of General Surgery, Shanghai Jiaotong \\ University Affiliated First People's Hospital, Shanghai 200080, China
}

*Correspondence: xuechun_wang@163.com

Received November 2, 2014 / Accepted February 18, 2015

\begin{abstract}
Receptor-interacting protein kinase 3 (RIP3) is a member of the RIP Ser/Thr kinase family, plays an important role in regulating cell survival, cell apoptosis and cell necrosis. However, the role of RIP3 in the carcinogenesis of colorectal cancer is still poorly understood.

We used quantitative PCR and Western blot analysis to examine RIP3 expression in primary colorectal cancer and paired normal colorectal mucosa. RIP3 clinicopathological significance was assessed by immunohistochemical staining in 112 cases of primary colorectal cancer paired with noncancerous tissues. The biological function of RIP3 overexpression was measured by CCK8 assay and plate colony formation assay. Dual staining with fluorescent Annexin V and propidium iodide (PI) was used to discriminate apoptotic or necrotic cell death.

RIP3 expression was significantly lower in colorectal cancer and associated with T stage, M stage and AJCC stage. Cox proportional hazard models showed that RIP3 expression was an independent prognostic factor for overall survival and disease-free survival in patients with colorectal cancer. Overexpression of RIP3 significantly suppressed the proliferation of colorectal cancer cells in vitro.

Our results suggest that RIP3 may function as a novel prognostic indicator after surgery and play a suppressive role in the colorectal carcinogenesis.
\end{abstract}

Key words: receptor-interacting protein kinase 3 (RIP3), colorectal cancer (CRC), novel prognostic indicator

Colorectal cancer (CRC) is one of the most common cancers worldwide [1]. CRC arises through the progressive accumulation of mutations in oncogenes and tumor-suppressor genes [2]. Several genes have been linked to genesis of CRC, however, the exact mechanisms of CRC are still poorly understood [3]. Although dramatic reduction in cancer mortality and prolonged patient survival after surgical resection and chemotherapy have been achieved clinically [4]. However, tumor recurrence and the chemoresistance remain the main factors for the failure of therapy [5]. Given the prevalence and the refractory of the $\mathrm{CRC}$, it is imperative to seek out a key gene associated with the progression and pathogenesis of CRC [6].

The human RIP3 gene is located on chromosome 14q11.2 and is related to multiple tumorigenesis [7-9]. RIP3, a member of the RIP Ser/Thr kinase family, has been characterized as a pro-apoptotic protein $[10,11]$. Full length ORF of the RIP3 gene contains $1557 \mathrm{bp}$ and encodes a polypeptide of
518 amino acids. It is an effective apoptosis-inducing protein [11]. RIP3 has been detected in multiple organs within human body including heart, liver, kidney, brain, skeletal muscle and pancreas. Nevertheless, some studies have indicated no expression of RIP3 in 23 tumor cells by Northern blot [12]. These results suggest that RIP3 is significant in cancer pathogenesis and progression as a tumor suppressor gene (TSG). However, its clinical significance and potential role in the pathogenesis of colorectal cancer remain unknown.

In this study, we explored the involvement of RIP3 in the progression of colorectal cancer by investigating its role in proliferation and metastasis.

\section{Patients and methods}

Human tissue specimens and patients information. A total of 112 colorectal cancer patients were enrolled in this 
study. No patients had received therapy prior to surgery. Pathological staging was based on the standard of American Joint Committee on Cancer (AJCC). The size of the primary tumor (T stage), presence of distant metastasis (M stage), degree of spread to regional lymph nodes (N stage) and AJCC stage were diagnosed by at least 2 pathologists. Our study comprised 69 male and 43 female patients in which surgery was performed by the same surgical team in the General Surgery Department of Shanghai Jiaotong University Affiliated First People's Hospital. The median age was 67 years (27-79 years). All of the tissue specimens were obtained with the patients' consent.

RNA extraction and quantitative real-time PCR. Total RNA was extracted using TRIzol reagent according to the manufacturer's instruction (Invitrogen, USA). First-strand cDNA was synthesized from $1 \mu$ lotal RNA using the RNA PCR Kit (Takara, Japan). RIP3 gene was amplified using forward primer 5'- TGCTGAAAGAAGTGGTGCTT-3', and reverse primer 5'-AGCCTCCCTGAAATGTGGAC-3'. GAPDH, forward primer 5'-TGACTTCAACAGCGACACCCA-3', reverse primer 5'-CACCCTGTTGCTGTAGCCAAA-3', was used as an internal control. qPCR was performed by Mastercycler ep Realplex (Eppendorf) with an IQTM SYBR Green Supermix Kit (BIO-RAD) according to the manufacturer's protocol. Cycling conditions were configured as follows: initial denaturation $\left(10 \mathrm{~min}\right.$ at $\left.95^{\circ} \mathrm{C}\right)$ and then 40 cycles of denaturation $\left(10 \mathrm{sec}\right.$ at $\left.95^{\circ} \mathrm{C}\right)$, annealing $\left(15 \mathrm{sec}\right.$ at $\left.58^{\circ} \mathrm{C}\right)$, extension $\left(1 \mathrm{~min}\right.$ at $\left.72^{\circ} \mathrm{C}\right)$, and with a final extension at $72^{\circ} \mathrm{C}$ for $5 \mathrm{~min}$. The fold change $\left(2^{-\Delta \Delta \mathrm{Ct}}\right)$ of RIP 3 expression was calculated using the formulas: $\mathrm{RIP} 3 \Delta \mathrm{Ct}=\mathrm{Avg}$.RIP3_Ct - Avg.GAPDH_Ct. and RIP3 $\Delta \Delta \mathrm{Ct}=\mathrm{RIP} 3 \Delta \mathrm{Ct}$ _tumor RIP3 $\Delta$ Ct_normal.

Western blot analysis. Tissue protein was extracted from four patients' colorectal cancer tissues and adjacent normal tissues using the Radio Immunoprecipitation Assay (RIPA) lysis buffer. Equivalent amounts of protein were electrophoresed on $10 \%$ SDS-polyacrylamide gel and transferred onto PVDF membranes. The membranes were blocked in $5 \%$ fat free milk with $0.1 \%$ Tween 20 for $1 \mathrm{~h}$ at room temperature, followed by incubation with primary antibodies (1:1000 dilution for RIP3 c-terminal, 1:1000 dilution for GAPDH, all purchased from Abcam, UK). Then blots were incubated with goat-antimouse immunoglobulin horseradish peroxidase conjugate secondary antibodies and visualized by enhanced chemiluminescence (Pierce Biotechnology, Rockford, IL, USA) and autoradiography.

Immunohistochemistry. Formalin-fixed, paraffinembeded samples of tumor and paired normal mucosa were consecutive sectioned into $4 \mu \mathrm{m}$. Immunostaining was performed using the primary antibody against RIP3 (1:200; Abcam, UK), and incubated with the secondary antibody (Genetech, Shanghai, China). Tissue sections were counterstained with Mayer's hematoxylin finally. The evaluation was based on the staining intensity of RIP3: 0 (negative), 1 (weak), 2 (strong). The cases were re-examined by another pathologist in the event of a discrepancy in scoring.
Cell culture and construction of the stable RIP 3 expressing cell line. The human colon cancer cell line RKO (purchased from Center of Shanghai Institutes for Biological Sciences, Type Culture Collection of Chinese Academy of Sciences) was cultured in DMEM medium supplemented with $10 \% \mathrm{FBS}$ (Gibco) and 1\% streptomycin, penicillin. All the cell lines were in a $5 \%$ humidified atmosphere at $37^{\circ} \mathrm{C}$. To determine the biofunction of RIP3 on cell biology characteristic, RKO cell line was transfected with plasmid coding for RIP3 protein. And the cells stably expressing RIP3 were selected using G418 after transfected with Lipofectamine (Invitrogen, USA).

Cell proliferation assay and colony formation assay. For cell proliferation assay, the stable transfection cells were seeded in the 96 well plates at a density of 1500 cells per well and cultured for $24,48,72,96$ and $120 \mathrm{~h}$, respectively. Then $100 \mu \mathrm{l}$ DMEM culture medium and $10 \mu \mathrm{l}$ CCK8 (Dojindo, Shanghai, China) were added into wells for another $2 \mathrm{~h}$ after removed the supernatant. Results were read on a microplate luminometer at the absorbance of $450 \mathrm{~nm}$.

For plate colony formation assay, cells were plated in a 6 well plate (800 cells/well) and incubated at $37^{\circ} \mathrm{C}$ for 12 days. After washed two times with PBS, fixed in paraformaldehyde for $30 \mathrm{~min}$, cells were stained with GIMSA solution for $20 \mathrm{~min}$ and images were obtained.

Migration and invasion assays. The migration and invasion assays were performed in a $8 \mu \mathrm{m}$ Transwell Inserts for 24 well plate with an uncoated membrane and a Matrigel (BD Biosciences, San Jose, CA) coated membrane, respectively. Briefly, the stable transfection cells $\left(1 \times 10^{5}\right.$ cells) prepared in DMEM medium supplemented with $2 \%$ FBS were loaded in the upper well, and medium supplemented with $15 \%$ FBS was placed in the lower wells as chemo-attractant. The nonmigrated and non-invasive cells on the upper chamber of the filter were gently removed with a cotton swab after a 24-hour incubation. The cells transferred to membrane were fixed, stained with $0.1 \%$ crystal violet solution and then thoroughly rinsed the inserts until the water ran clear. Finally, cells numbers in the insert were estimated in 6 random fields of views under an inverted microscope.

Apoptosis and cell cycle analysis. Cell apoptosis analyzed using the Annexin V-FITC PI Apoptosis Kit (BD Biosciences, Palo Alto, CA, USA). After a $48 \mathrm{~h}$ transfection, the transient transfection cells were harvested, rinsed twice with PBS and resuspended in $1 \times$ binding buffer. Transferred $100 \mu \mathrm{l}$ of cell suspension $\left(1 \times 10^{5}\right.$ cells $)$ to a $1.5 \mathrm{ml}$ EP tube. Added $5 \mu \mathrm{l}$ of FITC Annexin V and $5 \mu \mathrm{l}$ PI. Gently agitate the cells and incubated for $15 \mathrm{~min}$ at room temperature $\left(25^{\circ} \mathrm{C}\right)$ in the dark. Added $400 \mu \mathrm{l}$ of $1 \times$ binding buffer to each tube, and analyzed by flow cytometry immediately.

Statistical analysis. Data are shown as mean \pm SD. The oneway analysis of variance (ANOVA) was used to determine the statistical significance of differences between the two groups. The chi-square or Fisher's exact tests were used to calculate the realationships between RIP3 expression in different tissues and clinicopathological parameters. The overall survival 

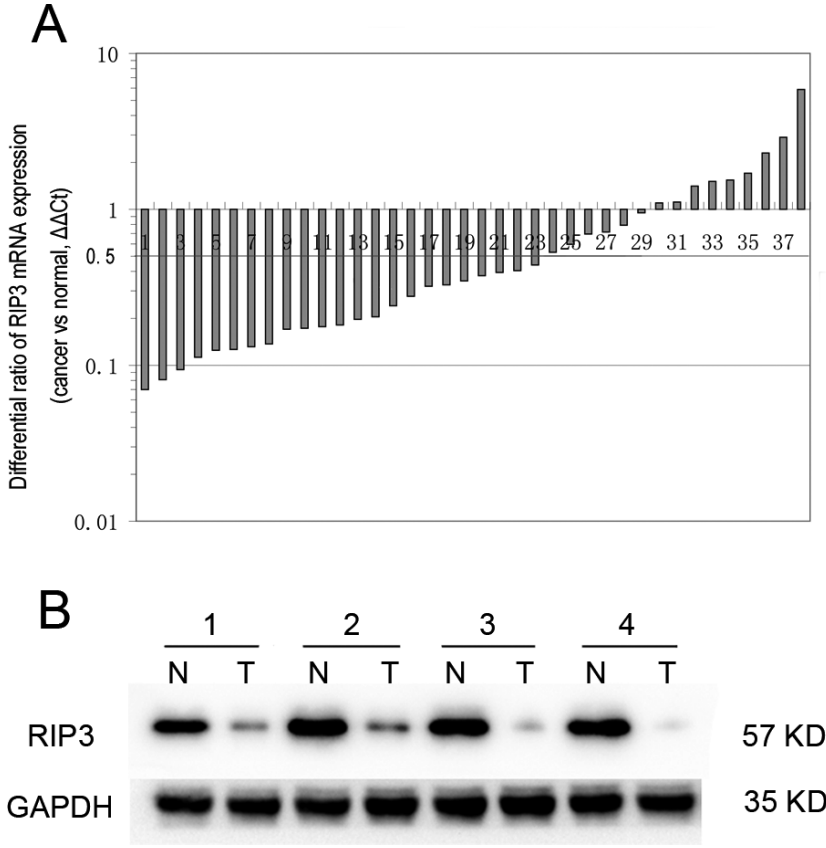

Figure 1. Expression of RIP3 in colorectal tumor tissues and adjacent normal mucosa. (A) Relative expression of RIP3 in 38 matched colorectal cancerous tissue specimens compared with in normal mucosa specimens. $2^{-\Delta \Delta \mathrm{Ct}}$ as a logarithmic scale was used to represent the fold change of in quantitative rt-PCR (B) RIP3 protein expression in 4 paired colorectal tissues measured by Western blot analysis.

(OS) rates and disease-free survival (DFS) were calculated using the Kaplan-Meier method, and the differences were examined by the log-rank test. The Cox proportional hazards model was used to investigate independent prognostic factors multivariate analysis and. $\mathrm{P}<0.05$ was considered statistical significant. All error bars represent for standard deviation. All statistical analyses performed by using the SPSS 19.0 (SPSS Inc, Chicago, IL).

\section{Results}

RIP3 was down regulated in colorectal cancerous tissue. Among 38 randomly selected, paired specimens used for qPCR analysis, 23 (60.5\%) colorectal cancers reduced to
$50 \%$ compared with adjacent non- cancerous tissues (Fig. 1A). The RIP3 mean relative quantification in the colorectal cancer tissue group and adjacent normal mucosa group were $5.49 \pm 0.84$ (1.27-6.34) and 4.02 \pm 0.53 (2.39-6.80), respectively. The difference in mRNA expression was significant. Of the 40 colorectal cancer samples, 4 samples showed strong down-regulation of RIP3 mRNA expression that was determined by $\mathrm{qPCR}$, and the RIP3 protein expression in the 4 samples was evaluated by western blot. As expected, the results confirmed that RIP3 protein levels were down regulated in cancerous tissues as compared with adjacent normal tissues (Fig. 1B).

Relationship between RIP3 tissue microarray immunohistochemistry and clinicopathological parameters. To further determine the clinicopathologic significance of RIP3 expression, immunohistochemistry was performed to detect the expression of RIP3 in 112 cases of primary colorectal cancer paired with noncancerous tissue. Of the 112 specimens, only 22 (19.6\%) showed RIP3 strong positive staining in colon cancerous tissue specimens, weak staining in 41 (36.6\%) samples, and negative staining in 49 (43.8\%) samples. In contrast, RIP3 was prominently expressed in normal mucosa, with strong positive staining in $79(70.5 \%)$ samples, weak staining in $30(27.8 \%)$ samples, and negative staining in $3(2.7 \%)$ samples (Table. 1, Fig. 2).

Associations between clinicopathological parameters and RIP3 expression were summarized in Table2. According to the statistical analysis, down-regulated RIP3 was associated with $\mathrm{T}$ stage $(\mathrm{P}=0.027)$, $\mathrm{M}$ stage $(\mathrm{P}=0.016)$ and AJCC stage $(\mathrm{P}=0.002)$, but no correlations were found with age, gender, tumor location, $\mathrm{N}$ stage, differentiation, and vessel invasion (Table. 2).

Low RIP3 expression associated with poor clinical outcome in human colorectal cancer. As showed in Fig. $3 \mathrm{~A}$ and B, we used Kaplan-Meier curves to illustrate the expression of RIP3 was significantly associated with overall survival (OS) and disease-free survival (DFS) rate (log rank test, $\mathrm{P}=0.004$, $\mathrm{P}=0.015$, respectively). We also found that RIP3 negative patients had an obviously lower OS and DFS rate than patients with RIP3 positive staining (OS: HR 2.02, 95\%CI 1.31-5.94, $\mathrm{P}<0.001$; DFS: HR 2.61, 95\%CI 1.44-4.73, $\mathrm{P}=0.002$, Table. 3 ).

Using a univariate Cox regression analysis, we found that both decreased OS and DFS were associated with $\mathrm{T}$ stage (OS $\mathrm{P}=0.025$, DFS $\mathrm{P}=0.015$ ), $\mathrm{N}$ stage (OS, DFS $\mathrm{P}<0.001$ ),

Table 1. Expression of RIP3 in normal colorectal mucosa and cancerous tissues

\begin{tabular}{|c|c|c|c|c|c|}
\hline \multirow[b]{2}{*}{ Tissue sample } & \multirow[b]{2}{*}{$\mathrm{n}$} & \multicolumn{3}{|c|}{ Expression of RIP3 } & \multirow[b]{2}{*}{$P$ value } \\
\hline & & Negative (\%) & $\begin{array}{c}\text { Weak } \\
\text { positive (\%) }\end{array}$ & $\begin{array}{c}\text { Strong } \\
\text { positive }(\%)\end{array}$ & \\
\hline Normal mucosa & 112 & $3(2.7)$ & $30(27.8)$ & $79(70.5)$ & \multirow{2}{*}{$<0.001^{*}$} \\
\hline Tumor & 112 & $49(43.8)$ & $41(36.6)$ & $22(19.6)$ & \\
\hline
\end{tabular}

$\mathrm{P}$-value is based on chi-square test

* Significant difference 


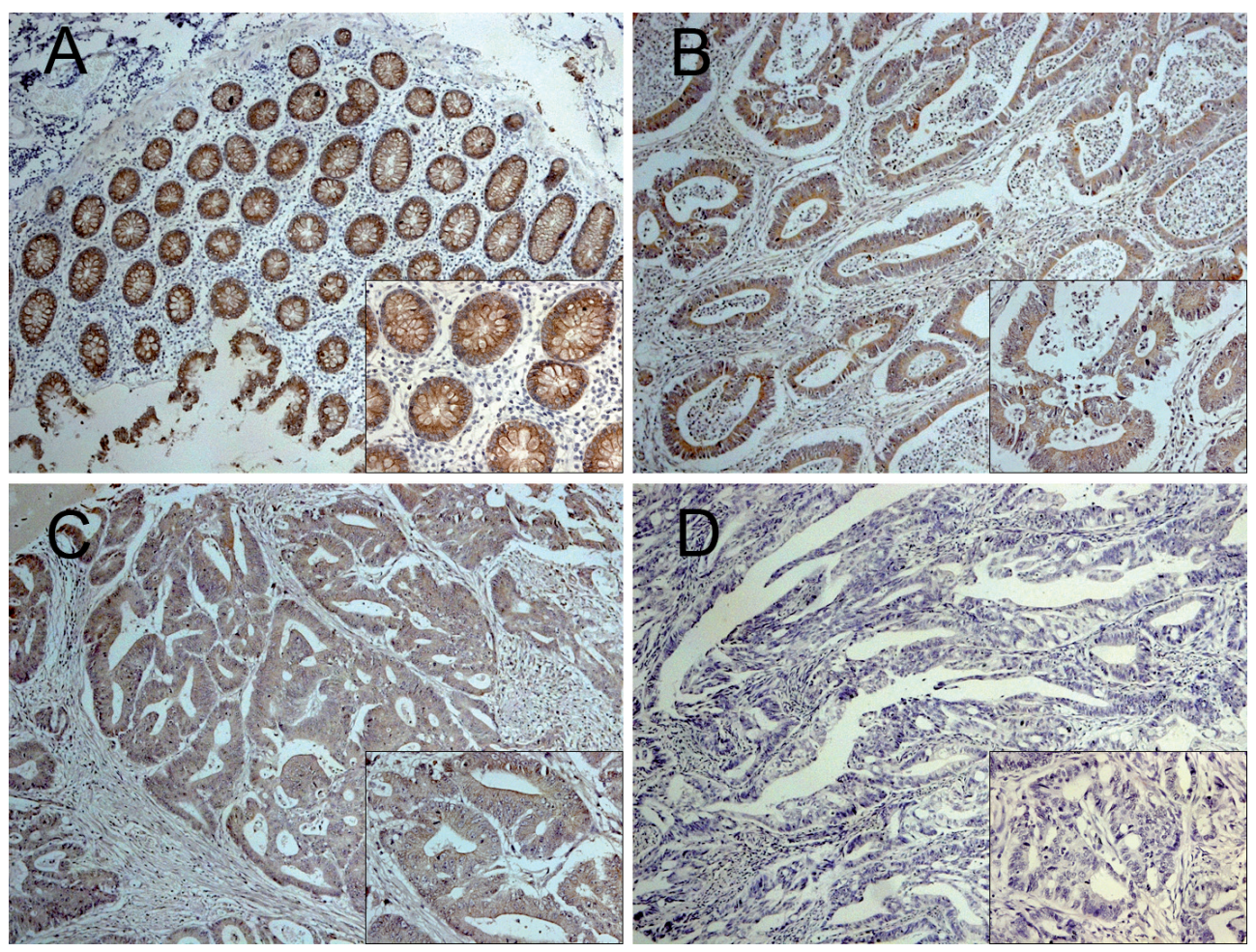

Figure 2. Characterization of RIP3 protein expression in human CRC tissues and corresponding normal mucosa by immunohistochemistry staining. (A) Strong positive RIP3 staining in normal colorectal epithelium. (B) Weak RIP3 staining in well differentiated tumors. (C) Weak RIP3 staining in moderately differentiated tumors. (D) Negative expression in poorly differentiated cancer. Original magnification $\times 100(\times 400$ for inset images).

M stage (OS, DFS $\mathrm{P}<0.001)$, AJCC stage (OS, DFS $\mathrm{P}<0.001)$, vessel invasion (OS, DFS $\mathrm{P}<0.001$ ), tumor differentiation (OS, DFS $\mathrm{P}<0.001$ ), RIP3 status (OS $\mathrm{P}<0.001$, DFS $\mathrm{P}=0.002$ ). However, the multivariate analysis demonstrated that there is no significant association between RIP3 expression and T stage, $\mathrm{M}$ stage, AJCC stage and vessel invasion, while RIP3 expression remains emerged as a significant prognostic factor for OS and DFS in patients with colon cancer (OS: HR 2.29,
A

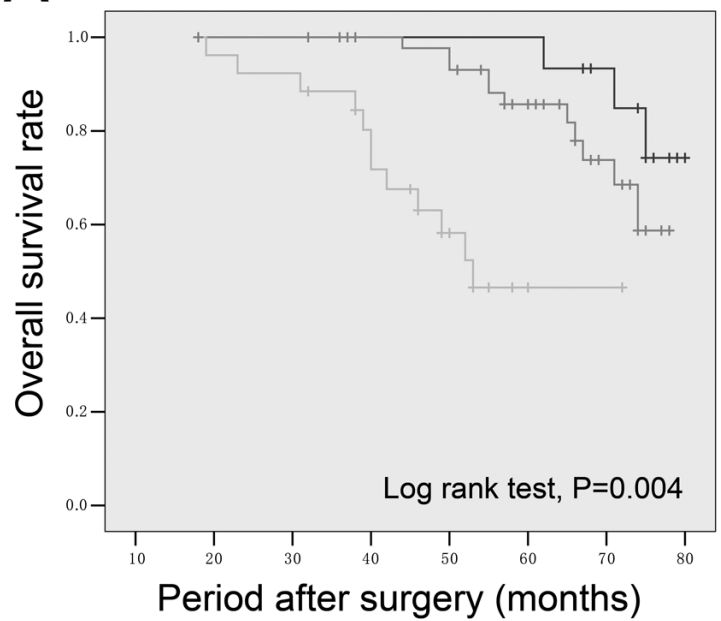

B

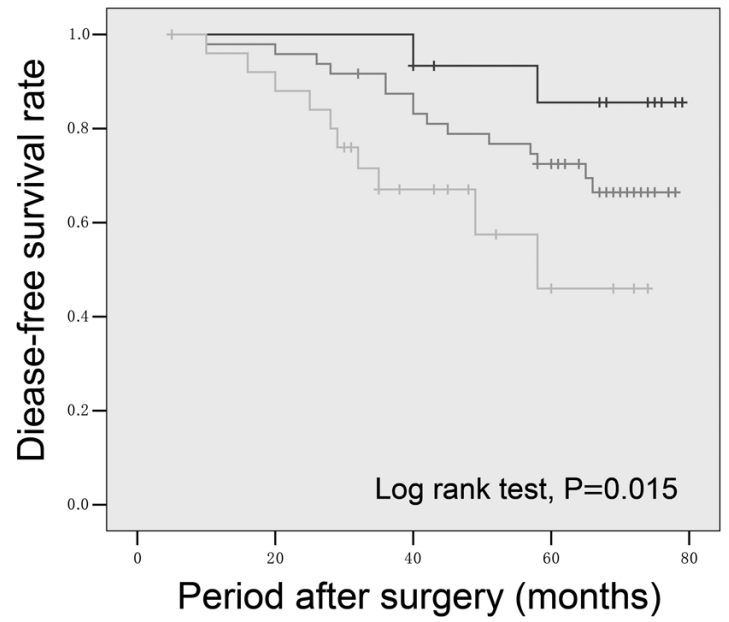

RIP3

$$
\begin{aligned}
& \sqcap \text { Strong } \\
& \square \text { Weak } \\
& \square \text { Negative } \\
& + \text { Strong-censored } \\
& + \text { Weak-censored } \\
& +\quad \text { Negative-censored }
\end{aligned}
$$

Figure 3. Survival curve of the colorectal cancer patients with regard to RIP3 expression. (A) The patients with RIP3 positive expression had a significantly higher overall survival and $(B)$ disease-free survival rate than the $R I P 3$ negative group $(P=0.004, P=0.015$, respectively). 
95\%CI 1.04-4.30, $\mathrm{P}=0.038$; DFS: HR 2.25, 95\%CI 1.10-4.74, $\mathrm{P}=0.002$, Table. 3 ).

Increased RIP3 expression inhibits the proliferation of colorectal cancer cells. Since RIP3 was down regulated in colorectal cancerous tissues and linked to the poor survival of colorectal cancer patients, we evaluated the effect of RIP3 on cell proliferation. RKO cell transfected with RIP3 cDNA or empty vector was used to analysis. Real-time PCR and western blot analysis were employed to confirm that RIP3 mRNA and protein level were significantly increased in overexpression cells, while mock and control transfected groups were hardly detectable (Fig. 4A, B). In the CCK8 assay, the results suggested that an obvious inhibition of cell growth in the groups of RIP3 overexpression compared with the mock and control groups at 24, 48, 72, 96 and $120 \mathrm{~h}$ time points (Fig. 4C). Consistent with the CCK8 assay, plate colony formation assay also proved that RIP3 overexpression caused significant inhibition of cancer cell clonogenicity compared with mock and control groups $(\mathrm{P}<0.05$, Fig. 4D).

Overexpression of RIP3 attenuated the migration and invasion of colorectal cancer cells. Since RIP3 was linked to distant metastasis of colorectal cancer, here we investigated

Table 2. Correlation between RIP3 expression and clinicopathological features in patients with colorectal cancer $(\mathrm{n}=112)$

\begin{tabular}{|c|c|c|c|c|c|}
\hline & \multirow[b]{2}{*}{$\mathrm{n}$} & \multicolumn{3}{|c|}{ RIP3 expression } & \multirow[b]{2}{*}{$\mathrm{P}$ value } \\
\hline & & Negative (49) & $\begin{array}{c}\text { Weak } \\
\text { positive (41) }\end{array}$ & $\begin{array}{c}\text { Strong } \\
\text { positive (22) }\end{array}$ & \\
\hline Age & & & & & 0.501 \\
\hline$<65$ & 48 & 22 & 19 & 7 & \\
\hline$\geq 65$ & 64 & 27 & 22 & 15 & \\
\hline Gender & & & & & 0.942 \\
\hline Male & 69 & 30 & 26 & 13 & \\
\hline Female & 43 & 19 & 15 & 9 & \\
\hline \multicolumn{6}{|l|}{ Location } \\
\hline Right & 54 & 23 & 20 & 11 & 0.733 \\
\hline Transverse & 8 & 5 & 3 & 0 & \\
\hline Left & 10 & 5 & 4 & 1 & \\
\hline Sid & 40 & 16 & 14 & 10 & \\
\hline \multicolumn{6}{|l|}{ T stage } \\
\hline $\mathrm{T} 1$ & 7 & 4 & 2 & 1 & $0.027^{\star}$ \\
\hline $\mathrm{T} 2$ & 15 & 2 & 5 & 8 & \\
\hline T3 & 45 & 22 & 16 & 7 & \\
\hline $\mathrm{T} 4$ & 45 & 21 & 18 & 6 & \\
\hline $\mathrm{N}$ stage & & & & & 0.686 \\
\hline No & 87 & 37 & 31 & 19 & \\
\hline N1 & 22 & 11 & 8 & 3 & \\
\hline $\mathrm{N} 2$ & 3 & 1 & 2 & 0 & \\
\hline M stage & & & & & $0.016^{*}$ \\
\hline M0 & 110 & 49 & 41 & 20 & \\
\hline M1 & 2 & 0 & 0 & 2 & \\
\hline AJCC stage & & & & & $0.002^{*}$ \\
\hline I & 17 & 0 & 6 & 11 & \\
\hline II & 70 & 25 & 25 & 10 & \\
\hline III & 21 & 10 & 10 & 1 & \\
\hline IV & 4 & 4 & 0 & 0 & \\
\hline Vessel invasion & & & & & 0.378 \\
\hline No & 110 & 49 & 40 & 21 & \\
\hline Yes & 2 & 0 & 1 & 1 & \\
\hline Differentiation & & & & & 0.088 \\
\hline High & 55 & 24 & 20 & 11 & \\
\hline Moderate & 46 & 16 & 20 & 10 & \\
\hline Low & 11 & 9 & 1 & 1 & \\
\hline
\end{tabular}

P-values are based on chi-squared or Fisher's exact test

* Significant difference 

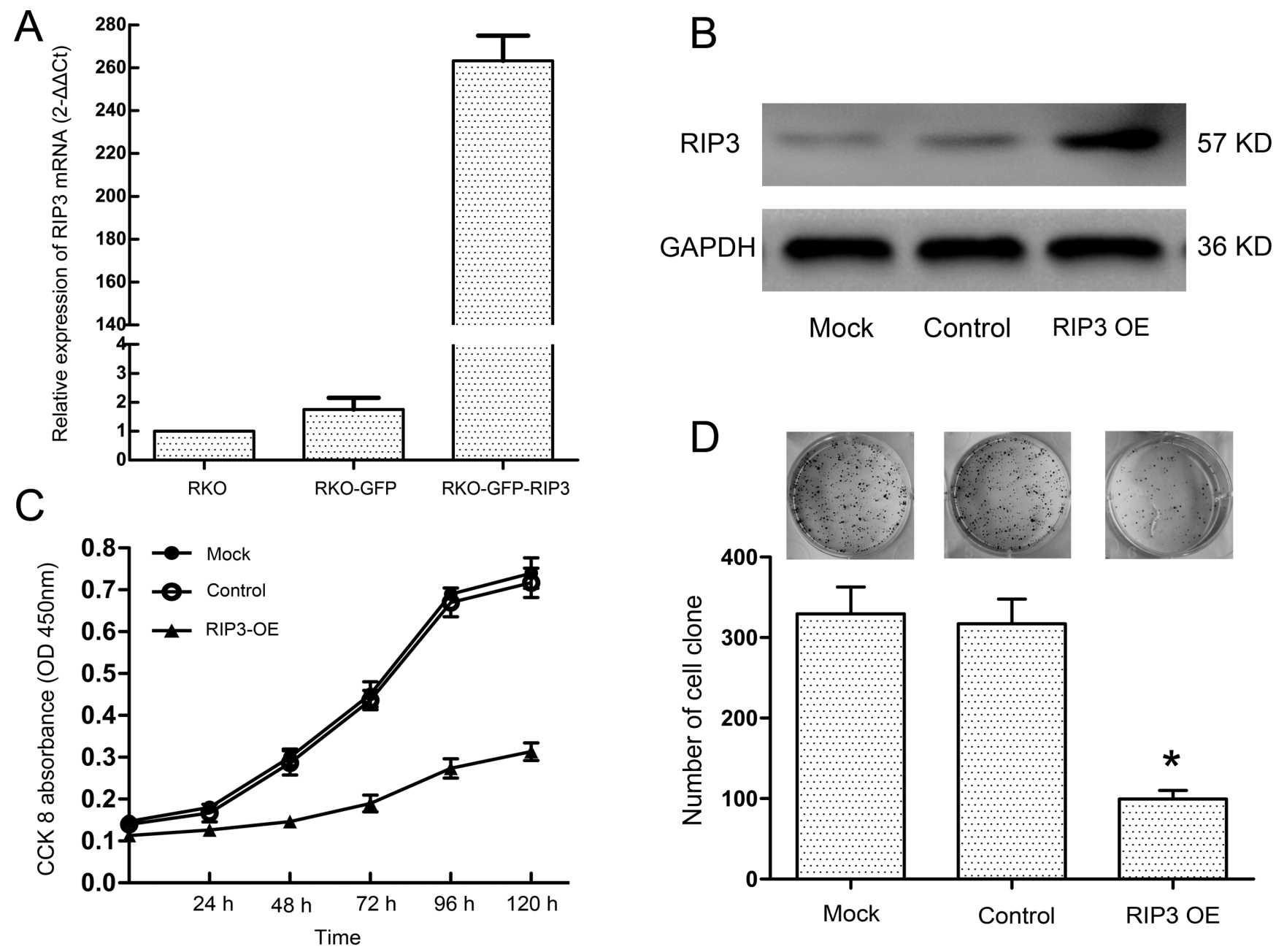

Figure 4. Effect of RIP3 overexpression on RKO cell proliferation. (A) The expression of RIP3 in uninfected (mock), transfected with empty vector (control) and plasmids coding for RIP3 (OE) groups were detected by Real-time PCR and (B) western blot analysis. (C) Cells growth curve measured by CCK8 assay and (D) Plate colony formation assays. $\left({ }^{\star} \mathrm{P}<0.05\right.$, vs control group, one-way analysis of variance)

Table 3. Univariate and multivariate Cox proportional hazard models for overall survival and disease-free survival

\begin{tabular}{|c|c|c|c|c|c|c|c|c|}
\hline \multirow[t]{3}{*}{ Variable } & OS & \multicolumn{7}{|c|}{ DFS } \\
\hline & Univariate & & Multivariate & & Univariate & & Multivariate & \\
\hline & $\mathrm{HR}(95 \% \mathrm{CI})$ & $\mathrm{P}$ value & $\mathrm{HR}(95 \% \mathrm{CI})$ & $\mathrm{P}$ value & $\mathrm{HR}(95 \% \mathrm{CI})$ & $\mathrm{P}$ value & $\mathrm{HR}(95 \% \mathrm{CI})$ & $P$ value \\
\hline Age & $1.64(0.57-2.74)$ & 0.52 & & & $1.38(0.56-2.82)$ & 0.63 & & \\
\hline Gender & $1.22(0.75-2.57)$ & 0.69 & & & $1.31(0.72-3.19)$ & 0.71 & & \\
\hline Location & $1.03(0.96-1.43)$ & 0.71 & & & $1.01(0.62-1.89)$ & 0.66 & & \\
\hline T stage & $1.98(1.02-3.64)$ & $0.025^{\star}$ & & & $1.83(1.11-3.71)$ & $0.015^{*}$ & & \\
\hline $\mathrm{N}$ stage & $5.92(3.92-10.33)$ & $<0.001^{*}$ & $2.52(1.39-4.92)$ & $0.006^{*}$ & $7.93(3.87-12.05)$ & $<0.001^{*}$ & $4.62(1.33-9.95)$ & $<0.001^{*}$ \\
\hline M stage & $11.93(3.07-24.73)$ & $<0.001^{\star}$ & & & $14.29(3.70-38.82)$ & $<0.001^{\star}$ & & \\
\hline AJCC stage & $4.83(2.68-8.42)$ & $<0.001^{\star}$ & & & $5.02(2.99-9.23)$ & $<0.001^{\star}$ & & \\
\hline Vessel invasion & $13.82(4.27-52.44)$ & $<0.001^{\star}$ & & & $21.76(5.28-62.77)$ & $<0.001^{\star}$ & & \\
\hline Differentiation & $3.84(2.40-6.23)$ & $<0.001^{\star}$ & $2.58(1.42-4.83)$ & $0.002^{*}$ & $3.23(1.96-7.88)$ & $<0.001^{\star}$ & $2.84(1.31-5.12)$ & $0.002^{\star}$ \\
\hline RIP3 & $2.02(1.31-5.94)$ & $<0.001^{\star}$ & $2.29(1.04-4.30)$ & $0.038^{\star}$ & $2.61(1.44-4.73)$ & $0.002^{*}$ & $2.25(1.10-4.74)$ & $0.025^{*}$ \\
\hline
\end{tabular}

HR: hazard radio, CI: confidence interval

P-values are based on Wald test

* Significant difference 
A
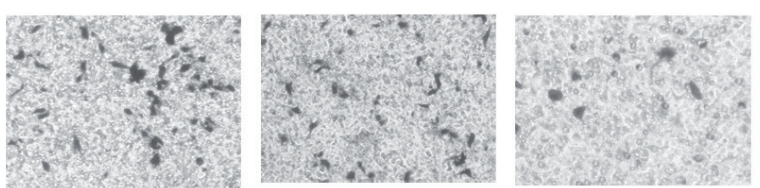

B
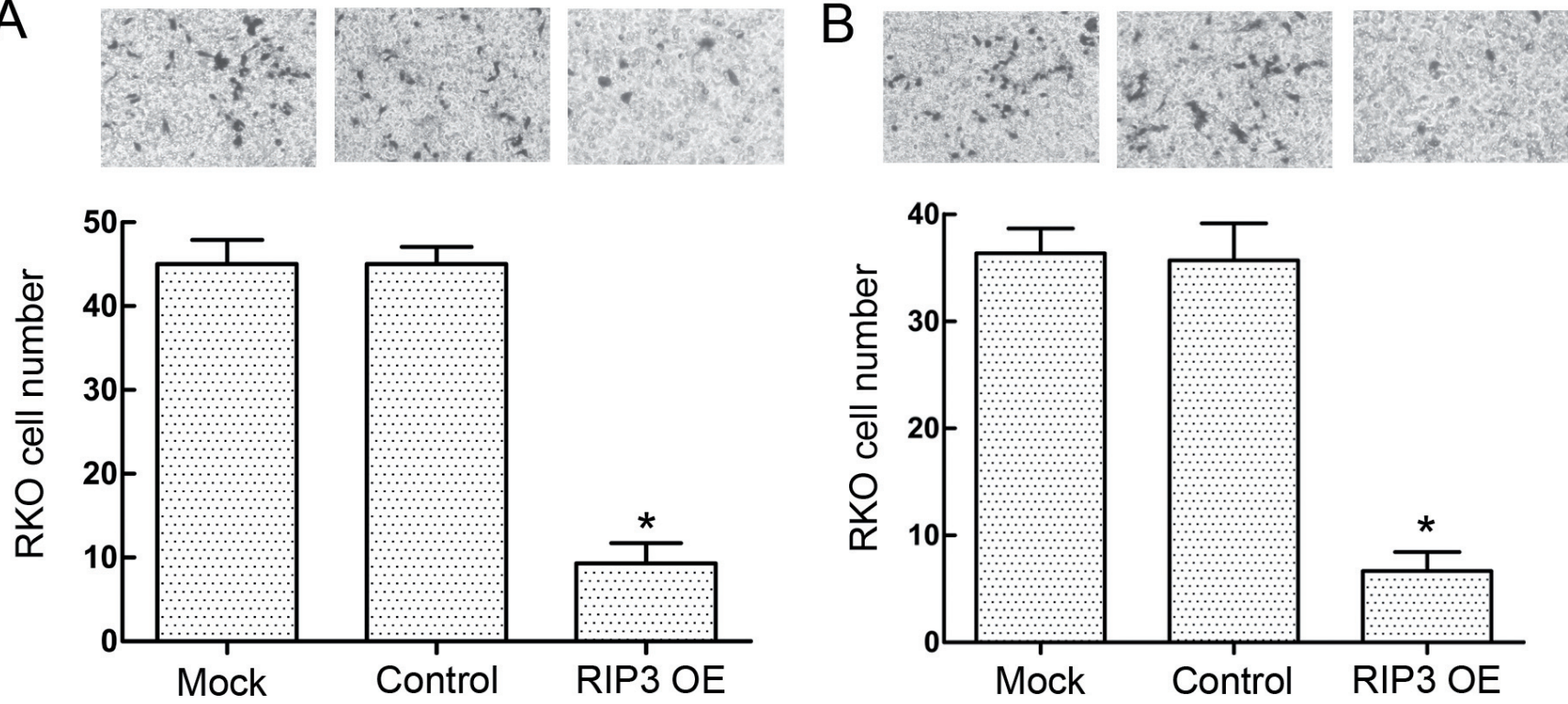

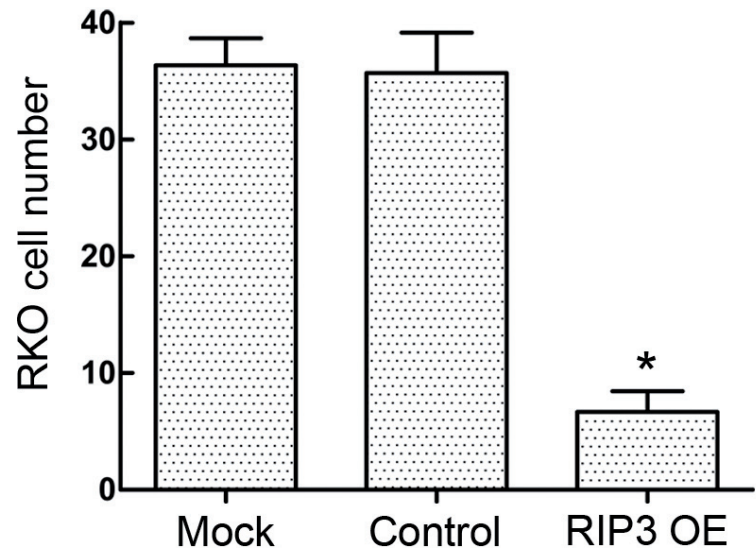

Figure 5. Overexpression of RIP3 suppressed the migration and invasion of colorectal cancer cells. (A) The images show migration of RKO cells through the micropore membrane without Matrigel. (B) The images show invasion of $\mathrm{RKO}$ cells through the micropore membrane with $\mathrm{Matrigel} .200 \times .\left({ }^{\star} \mathrm{P}<0.05\right.$, vs control group, one-way analysis of variance)

the role of RIP3 in migration and invasion in vitro. Using the migration chambers, the RIP3 overepression groups were proved to exhibit a significantly lower migratory ability than those of control cells $(\mathrm{P}<0.05$, Fig. 5A). Similarly, RIP3 overepression groups also attenuated the invasion potential in $\mathrm{RKO}$ cell ( $\mathrm{P}<0.05$, Fig. 5B).

Overexpression of RIP3 induces apoptosis of colorectal cancer cells. We next investigated how RIP3 might affect cell death. After 48 hours plasmids trasfected, flow cytometric analysis following annexin-V FITC and PI labeling demonstrated that overexpression of RIP3 clearly induced apoptosis in $\mathrm{RKO}$ cell, but not in the mock and control groups (parent RKO cell and empty vector transfected RKO cell, respectively), and the effect of RIP3 overexpression can be blocked by a pan-caspase inhibitor, z-VAD (Fig 6A, B, C, D). These results indicated that RIP3 overexpression induces apoptosis in RKO cell by the caspase dependent death signaling.

\section{Discussion}

Colorectal cancer is one of the most common malignances in the world. Tumor recurrence and resistance to apoptosis are the main factor for failure of colorectal cancer therapy following surgery. RIP3 has recently been outlined as a key gene involved in the regulation of apoptosis and necroptosis [13]. RIP3 was proved to play an important role in some malignant tumors, including hepatocarcinoma, chronic lymphocytic leukemia, osteosarcoma and glioblastoma [14-17]. However, the expression of RIP3 and its potential role in colorectal cancer remains elusive. To the best of our knowledge, this is the first report on the expression and function of RIP3 in colorectal cancer.

In the present study, we show that the expression of RIP3 is significantly decreased in colorectal cancer compared with normal tissue. Some similar studies also revealed that the ratio of RIP3 $\gamma$ (a splice variants of RIP3 possess a shorter $\mathrm{C}$ terminus) to RIP3 is increased in colon and lung cancers obviously relative to the paired normal tissues, indicating that the mutant RIP3 lose c-terminal might associated with tumorigenesis [18]. Moreover, we also found that decreased expression of RIP3 was related to some disadvantageous clinicopathologic parameters such as T stage, $\mathrm{M}$ stage and AJCC stage. To confirm the results above, we estimated that overexpression of RIP3 decreased the proliferation and metastasis of human colorectal cancer cells in vitro. Finally, we provide the evidence that RKO colorectal cancer cells were induced to apoptosis when RIP3 was overexpressed. In accordance with our findings, RIP3 has been characterized as a pro-apoptotic protein involved in the TNFR1-FADD signaling pathway [18]. And previous studies have proved that overexpression of RIP3 in Hela, 293E, Phoenix-A cells, MCF7 cells could lead to cell death which present apoptotic morphological features and activated caspases could be detected [10-12, 19]. The effect of apoptosis was related to the RIP3 c-terminal [20]. Besides, our Immunohistochemistry results indicated that RIP3 protein was distributed at cytoplasm. However, it was relocated to the nucleus mainly after leptomycin B (LMB) treatment at $37^{\circ} \mathrm{C}$ [21]. As many nucleocytoplasmic shuttling protein, such as APC and P53, it may be a potential tumor suppressor gene $[22,23]$. 

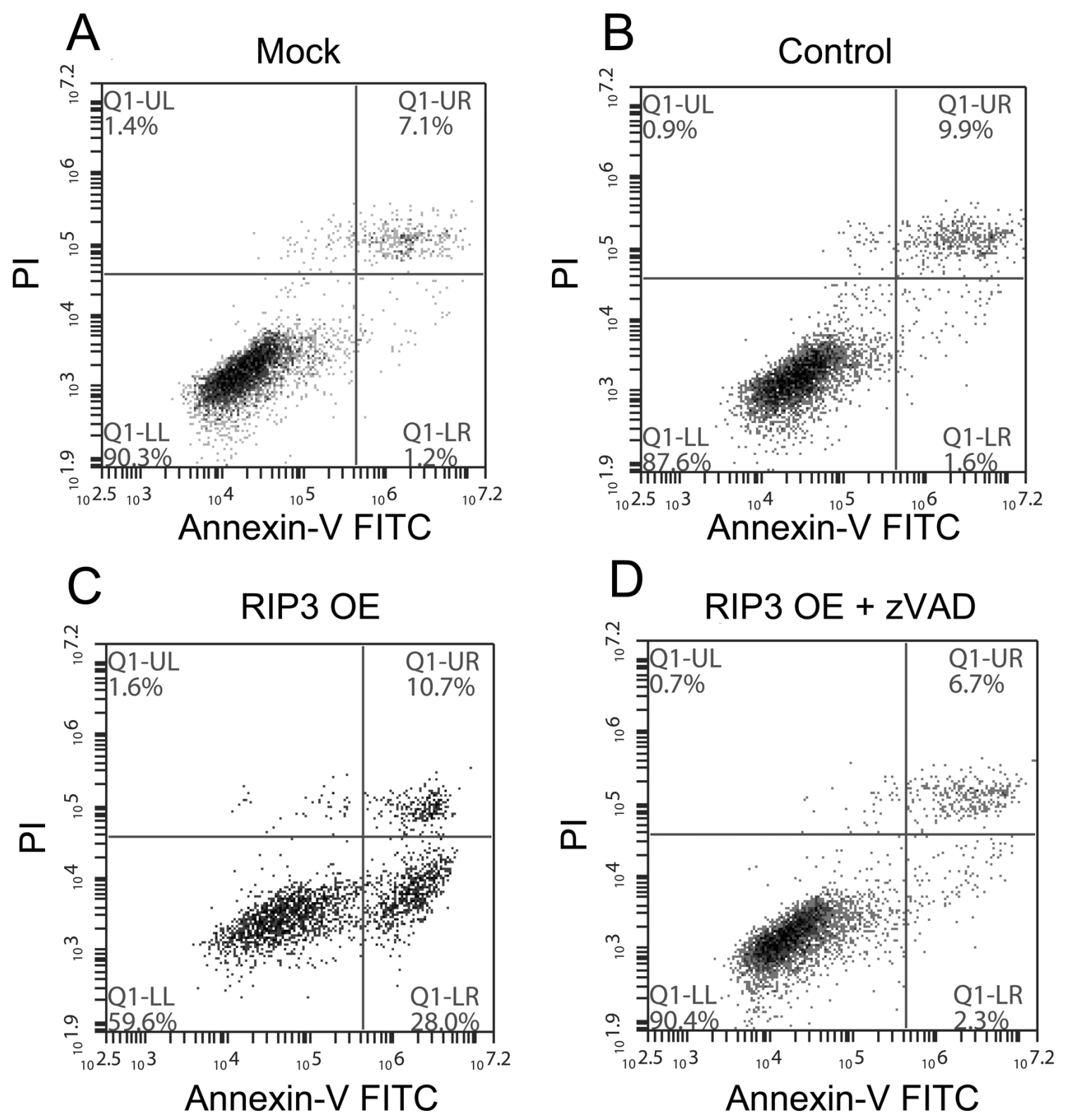

Figure 6. The effect of RIP3 overexpression on apoptosis. (A) RKO cells and (B) treated them with empty vector (control), (C) RIP3 overexpression plasmids (OE) and (D) zVAD + RIP3 overexpression plasmids were double-stained with Annexin V-FITC and PI, and then analyzed by flow cytometry.

The detailed mechanism of RIP3-induced apoptosis is largely unknown. Sun et al. showed that RIP3 interact with caspase 2, 8, 9 and 10 [11]. Kasof et al proved that RIP3 induced apoptosis is related to caspase 2, 3, 7, and 10 by different caspase inhibitors [12]. Nevertheless, an important number of papers studied the influence of RIP3 on NF- $\kappa B$ activation which regulate the ability of tumor cells to resist apoptosis [24]. But the results were conflicting. Some papers reported that NF- $\kappa B$ is activated by RIP3 overexpression [10, 12, 21]. In contrast, some other authors argue that RIP3 has no effect on NF- $\kappa B$ activation but rather acts attenuating NF- $\kappa B$ activation which mediated by RIP1 and TNFR1 $[25,26]$, because the NF- $\mathrm{KB}$ act as a negative regulator to apoptosis of tumor [27]. Our results might be more supportive of the latter view. The function of RIP3 is not so simple. Three independent studies unequivocally have demonstrated that RIP3 was required for necrosis in some cell lines and RIP $3^{--}$mice exhibited severely impaired virus-induced tissue necrosis [28-30]. We considered that the different manners of cell death are probably because of different cell types and inducement conditions. Although 
the overexpression experiments alone are insufficient to provide strong evidence. However, our data prove that RIP3 has great potential value for prognosis for colorectal cancer. Our future work will aim to elucidate the molecular mechanism of RIP3. Ultimately, we hope to find a new effective therapeutic strategy.

In conclusion, we found that RIP3 expression in colorectal cancer tissues was significantly down-regulated compared with the adjacent normal tissues, and was correlated with the clinical features of T stage, M stage and AJCC stage. Furthermore, aberrant up-regulation of RIP3 inhibits proliferation, migration and invasion of colorectal cancer cells. The preliminary results above need to be confirmed in a larger, prospective, controlled, clinical study.

\section{References}

[1] SIEGEL R, DESANTIS C, JEMAL A. Colorectal cancer statistics, 2014. CA: a cancer journal for clinicians 2014; 64: 104-117. http://dx.doi.org/10.3322/caac. 21220

[2] SJOBLOM T, JONES S, WOOD LD, PARSONS DW, LIN J, et al. The consensus coding sequences of human breast and colorectal cancers. Science 2006; 314: 268-274. http://dx.doi. org/10.1126/science.1133427

[3] GOEL A, BOLANDCR. Recent insights into the pathogenesis of colorectal cancer. Current opinion in gastroenterology 2010;26: 47-52. http://dx.doi.org/10.1097/MOG.0b013e328332b850

[4] YAN DW, LI DW, YANG YX, XIA J, WANG XL, et al. Ubiquitin $\mathrm{D}$ is correlated with colon cancer progression and predicts recurrence for stage II-III disease after curative surgery. British journal of cancer 2010; 103: 961-969. http://dx.doi. org/10.1038/sj.bjc.6605870

[5] CHANG A. Chemotherapy, chemoresistance and the changing treatment landscape for NSCLC. Lung cancer 2011; 71: 3-10. http://dx.doi.org/10.1016/j.lungcan.2010.08.022

[6] CATENACCI DV, KOZLOFF M, KINDLER HL, POLITE B. Personalized colon cancer care in 2010. Seminars in oncology 2011; 38: 284-308. http://dx.doi.org/10.1053/j. seminoncol.2011.01.001

[7] SHAO L, CUI Y, LI H, LIU Y, ZHAO H, et al. CMTM5 exhibits tumor suppressor activities and is frequently silenced by methylation in carcinoma cell lines. Clinical cancer research : an official journal of the American Association for Cancer Research 2007; 13: 5756-5762. http://dx.doi. org/10.1158/1078-0432.CCR-06-3082

[8] SIHN CR, LEE YS, JEONG JS, PARK K, KIM SH. CANu1, a novel nucleolar protein, accumulated on centromere in response to DNA damage. Genes to cells : devoted to molecular \& cellular mechanisms 2008; 13: 787-796. http://dx.doi. org/10.1111/j.1365-2443.2008.01205.x

[9] PRASAD RB, HOSKING FJ, VIJAYAKRISHNAN J, PAPAEMMANUIL E, KOEHLER R, et al. Verification of the susceptibility loci on 7p12.2,10q21.2, and 14q11.2 in precursor B-cell acute lymphoblastic leukemia of childhood. Blood 2010; 115: 1765-1767. http://dx.doi.org/10.1182/blood-2009-09$\underline{241513}$
[10] SUN X, LEE J, NAVAS T, BALDWIN DT, STEWART TA, et al. RIP3, a novel apoptosis-inducing kinase. J Biol Chem 1999; 274: 16871-16875. http://dx.doi.org/10.1074/ jbc. 274.24 .16871

[11] YU PW, HUANG BC, SHEN M, QUAST J, CHAN E, et al. Identification of RIP3, a RIP-like kinase that activates apoptosis and NFkappaB. Current biology : CB 1999; 9: 539-542. http://dx.doi.org/10.1016/S0960-9822(99)80239-5

[12] KASOF GM, PROSSER JC, LIU D, LORENZI MV, GOMES BC. The RIP-like kinase, RIP3, induces apoptosis and NFkappaB nuclear translocation and localizes to mitochondria. FEBS letters 2000; 473: 285-291. http://dx.doi.org/10.1016/ S0014-5793(00)01473-3

[13] DECLERCQ W, VANDEN BERGHE T, VANDENABEELE P. RIP kinases at the crossroads of cell death and survival. Cell 2009; 138: 229-232. http://dx.doi.org/10.1016/j. cell.2009.07.006

[14] COUPIENNE I, FETTWEIS G, PIETTE J. RIP3 expression induces a death profile change in U2OS osteosarcoma cells after 5-ALA-PDT. Lasers in surgery and medicine 2011; 43: 557-564.

[15] COUPIENNE I, FETTWEIS G, RUBIO N, AGOSTINIS P, PIETTE J. 5-ALA-PDT induces RIP3-dependent necrosis in glioblastoma. Photochemical \& photobiological sciences : Official journal of the European Photochemistry Association and the European Society for Photobiology 2011; 10: 1868-1878. http://dx.doi.org/10.1039/c1pp05213f

[16] LIU P, XU B, SHEN W, ZHU H, WU W, et al. Dysregulation of TNFalpha-induced necroptotic signaling in chronic lymphocytic leukemia: suppression of CYLD gene by LEF1. Leukemia 2012; 26: 1293-1300. http://dx.doi.org/10.1038/ $\underline{\text { leu.2011.357 }}$

[17] VUCUR M, REISINGER F, GAUTHERON J, JANSSEN J, RODERBURG C, et al. RIP3 inhibits inflammatory hepatocarcinogenesis but promotes cholestasis by controlling caspase-8- and JNK-dependent compensatory cell proliferation. Cell reports 2013; 4: 776-790. http://dx.doi.org/10.1016/j. celrep.2013.07.035

[18] FENG S, MA L, YANG Y, WU M. Truncated RIP3 (tRIP3) acts upstream of FADD to induce apoptosis in the human hepatocellular carcinoma cell line QGY-7703. Biochem Biophys Res Commun 2006; 347: 558-565. http://dx.doi.org/10.1016/j. bbrc.2006.06.118

[19] PAZDERNIK NJ, DONNER DB, GOEBL MG, HARRINGTON MA. Mouse receptor interacting protein 3 does not contain a caspase-recruiting or a death domain but induces apoptosis and activates NF-kappaB. Molecular and cellular biology 1999; 19: 6500-6508.

[20] FENG S, YANG Y, MEI Y, MA L, ZHU DE, et al. Cleavage of RIP3 inactivates its caspase-independent apoptosis pathway by removal of kinase domain. Cellular signalling 2007; 19: 2056-2067. http://dx.doi.org/10.1016/j.cellsig.2007.05.016

[21] YANG Y, MA J, CHEN Y, WU M. Nucleocytoplasmic shuttling of receptor-interacting protein 3 (RIP3): identification of novel nuclear export and import signals in RIP3. J Biol Chem 2004; 279: 38820-38829. http://dx.doi.org/10.1074/ jbc.M401663200 
[22] ROSIN-ARBESFELD R, CLIFFE A, BRABLETZ T, BIENZ $M$. Nuclear export of the APC tumour suppressor controls beta-catenin function in transcription. The EMBO journal 2003; 22: 1101-1113. http://dx.doi.org/10.1093/emboj/ $\underline{\mathrm{cdg} 105}$

[23] NIE L, SASAKI M, MAKI CG. Regulation of p53 nuclear export through sequential changes in conformation and ubiquitination. J Biol Chem 2007; 282: 14616-14625. http:// dx.doi.org/10.1074/jbc.M610515200

[24] KARIN M. Nuclear factor-kappaB in cancer development and progression. Nature 2006; 441: 431-436. http://dx.doi. org/10.1038/nature04870

[25] SUN X, YIN J, STAROVASNIK MA, FAIRBROTHER WJ, DIXIT VM. Identification of a novel homotypic interaction motif required for the phosphorylation of receptor-interacting protein (RIP) by RIP3. J Biol Chem 2002; 277: 9505-9511. http://dx.doi.org/10.1074/jbc.M109488200

[26] VAN HERREWEGHE F, FESTJENS N, DECLERCQ W, VANDENABEELE P. Tumor necrosis factor-mediated cell death: to break or to burst, that's the question. Cellular and molecular life sciences : CMLS 2010; 67: 1567-1579. http:// dx.doi.org/10.1007/s00018-010-0283-0

[27] GRETEN FR, WEBER CK, GRETEN TF, SCHNEIDER G, WAGNER M, et al. Stat3 and NF-kappaB activation prevents apoptosis in pancreatic carcinogenesis. Gastroenterology 2002; 123: 2052-2063. http://dx.doi.org/10.1053/ gast. 2002.37075

[28] CHO YS, CHALLA S, MOQUIN D, GENGA R, RAY TD, et al. Phosphorylation-driven assembly of the RIP1-RIP3 complex regulates programmed necrosis and virus-induced inflammation. Cell 2009; 137: 1112-1123. http://dx.doi.org/10.1016/j. cell.2009.05.037

[29] HE S, WANG L, MIAO L, WANG T, DU F, et al. Receptor interacting protein kinase-3 determines cellular necrotic response to TNF-alpha. Cell 2009; 137: 1100-1111. http:// dx.doi.org/10.1016/j.cell.2009.05.021

[30] ZHANG DW, SHAO J, LIN J, ZHANG N, LU BJ, et al. RIP3, an energy metabolism regulator that switches TNF-induced cell death from apoptosis to necrosis. Science 2009; 325: 332-336. http://dx.doi.org/10.1126/science. 1172308 